\title{
Curative Role of Dithiophenolato Titanium (IV)-Chitosan Nanocomposite Complex Against Carbon Tetrachloride-Induced Liver Injuries
}

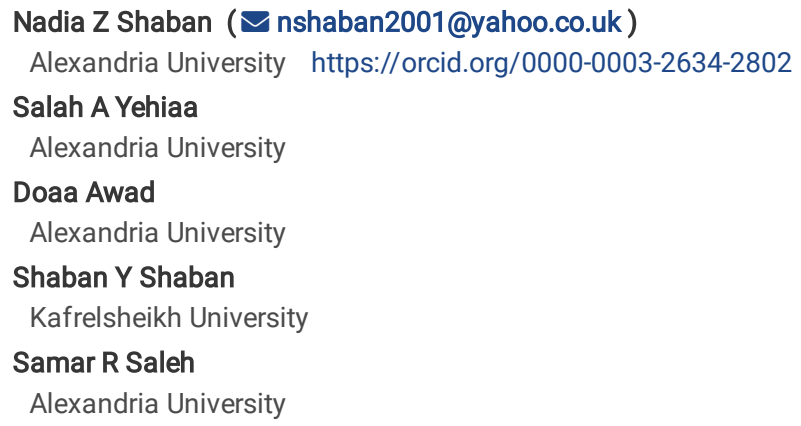

Research

Keywords: Chitosan nanoparticles, dithiophenolatotitanium (IV) complex, liver injury, apoptosis, Oxidative stress, G2/M arrest.

Posted Date: April 5th, 2021

DOI: https://doi.org/10.21203/rs.3.rs-320823/v1

License: (c) (7) This work is licensed under a Creative Commons Attribution 4.0 International License. Read Full License 


\section{Abstract \\ Background}

Titanium-based compounds have been incorporated as promising antineoplastic metals. In our previous studies, dithiophenolato titanium (IV) Complex "DBT" and its chitosan nanocomposite "DBT-CSNPs" were prepared and we showed that these compounds have antibacterial activities, cytotoxic, and have abilities to bind with DNA helixes. Therefore, in this study, we evaluated the LD50 values of dithiophenolato titanium (IV)-complex (DBT) and its high thermal stable chitosan nanoparticles (DBT-CSNPs). Then their therapeutic effects against liver injuries induced by carbon tetrachloride $\left(\mathrm{CCl}_{4}\right)$ were assessed and compared with cisplatin treatment. Additionally, the anti-proliferative activity of DBT and DBT-CSNPs against human liver cancer (HepG2) cell lines through the analysis of the cell cycle was evaluated.

\section{Methods}

Nine groups of rats were prepared: normal, DBT, DBT-CSNPs, CSNPs, $\mathrm{CCl}_{4}, \mathrm{CCl}_{4}$-DBT, $\mathrm{CCl}_{4}$-DBT-CSNPs, $\mathrm{CCl}_{4}$-CSNPs and CCl 4 -Cisplatin. Liver histopathology and the biochemical markers involving oxidative stress, apoptosis, liver and kidney functions, and lipid profile were determined.

\section{Results}

The results revealed that the treatment with DBT-CSNPs and DBT after $\mathrm{CCl}_{4}$ administration abolished liver damage since it reduced the apoptosis induced by $\mathrm{CCl}_{4}$ via the reduction of DNA fragmentation, Bax and caspase- 8 with an elevation of $\mathrm{Bcl} 2$ and $\mathrm{Bcl}$ /Bax ratio. Also, these treatments caused nonsignificant changes in the markers of oxidative stress. Therefore, liver histopathology and functions, lipid profile, and kidney functions were improved. Cisplatin treatment reduced liver injury with a degree less than DBT-CSNPs and DBT, but it induced nephrotoxicity. Administration of DBT-CSNPs and DBT to healthy rats for 14 days has no adverse effect. Also, the results showed that DBT-CSNPs and DBT inhibited the proliferation of HepG2 cells by arresting cells in the G2/M phase and inducing cell death.

\section{Conclusion}

DBT-CSNPs and DBT have a therapeutic effect against CCl4-induced liver injuries via the reduction of apoptosis induced by CCl4. Moreover, both compounds have antineoplastic activities against the HepG2 cell line. In all cases, DBT-CSNPs have a greater effect due to their nanostructure. Therefore, both compounds can be used in the pharmacological fields, particularly DBT-CSNPs.

\section{Highlights}

1. LD50 values of DBT and DBT-CS are about 1350 and $1800 \mathrm{mg} / \mathrm{Kg}$, respectively.

2. DBT and DBT-CSNPs showed antiapoptotic effects against $\mathrm{CCl}_{4}$-induced hepatotoxicity.

3. Treatment with DBT and DBT-CS NPs improved hepato- and nephro-toxicity induced by $\mathrm{CCl}_{4}$.

4. DBT-CS NPs has a potent therapeutic-effect than DBT and both are better than cisplatin

5. DBT-CS NPs have antiproliferative activities and arrested HepG2 cells at G2/M phase.

\section{Introduction}

The liver is the largest tough organ in the body and is requisite for survival. The liver has numerous functions including the synthesis of proteins, glucose, bile, and clotting factors, besides breaking down hormones, certain drugs, and xenobiotics [1, 2]. Hepatic metabolism of medicinal agents and toxins as carbon tetrachloride $\left(\mathrm{CCl}_{4}\right)$ involves disturbed hepatic cell biochemistry with the augmented generation of free radicals and reactive oxygen species (ROS) and redox imbalance with secondary deterioration to proteins, lipids, carbohydrates, and nucleic acids [3, 4]. The xenobiotic-induced hepatotoxicity ranging from a subclinical anicteric state to severe necroinflammatory hepatitis (acute, recurrent, or chronic) and cirrhosis, relies on the dosage, nature, and period of exposure to the xenobiotics, the antioxidant defense, and attendant exposure to another disease or xenobiotics [1, 2]. ROS and reactive nitrogen species (RNS) are well known for playing a double function as both mischievous and beneficial species. The "two-faced" of ROS is adduced by a growing body of proof that ROS within cells act as secondary messengers in intracellular signaling cascades, which stimulate and preserve the oncogenic phenotype of cancer cells, while, ROS can also prompt cellular senescence and apoptosis and can thus function as antitumorigenic species [5, 6]. The cumulative production of ROS/RNS through either endogenous or exogenous insults is titled oxidative stress (OS) and is popular for numerous types of cancer cells that are connected with altered redox organization of cellular signaling paths. OS prompts a cellular redox imbalance that has been found to be present in different cancer cells as compared with normal cells; the redox imbalance thus may be linked to oncogenic inducement [7].

$\mathrm{CCl}_{4}$ is an industrial chemical found in refrigerants and solvents for waxes, varnishes and other materials. $\mathrm{CCl}_{4}$ is one of the most potent hepatotoxins, so it is widely used in scientific research to evaluate hepatoprotective agents [8]. Chronic exposure to $\mathrm{CCl}_{4}$ can cause liver and kidney damage and could result in cancer $[5,6]$. In liver, $\mathrm{CCl}_{4}$ is metabolized by cytochrome $\mathrm{P} 450$ into trichloromethyl radical $\left({ }^{\circ} \mathrm{CCl}_{3}\right)$ which converts to trichloromethylperoxy radicals $\left(\mathrm{CCl}{ }_{3} \mathrm{OO}\right.$ ) $[5$, 6]. 
Liver diseases represent a major cause of serious and public health problems leading to morbidity and mortality in worldwide and Egypt [8, 9]. Therefore, scientists are working on discovering new treatments for liver diseases that are effective and do not have side effects or have minor side effects. During the last 100 years, metals have been used in therapy and other medical applications in a rational manner. A wide variety of metallodrugs have been investigated which showed excellent anticancer results [10-13]. Gallium, titanium, platinum, ruthenium, tin, gold and cobalt have shown effective anticancer activities [10, 13].

Titanium Ti(IV) as a biomaterial is generally used for orthopedic implants such as the substitution of teeth and bone [14]. The advantage of titanium compounds lies in their elevated effectiveness and low toxicity. In biological mediums, hydrolysis of Ti(IV) complexes leads to safe and inert titanium oxide $\left(\mathrm{TiO}_{2}\right)$ [15]. The next generation of phenolato-based complexes showed markedly improved stability and high activity. Ti(IV) is chiefly accumulated in the cellular nucleic acid-rich areas, mainly in the nucleic chromatin of tumor cells [16] and interacts with the oxygen (hard base) of the phosphoesters and with the nitrogen of the nucleobase in DNA that leads to cell cycle inhibition. Phenolato Ti complexes are considered a novel and efficient anticancer drug with nontoxic effect at extents of the effective doses $[17,18]$. In 2012, we synthesized the dithiophenolate titanium (IV)-complex $\left[\left\{T i\left(\mathrm{~N}_{2} \mathrm{H}_{2} \mathrm{~S}_{2}\right)\left(\mathrm{O}^{\mathrm{i} P r}\right)\right\} \mathrm{C}_{2}\right](\mathrm{DBT}$ :

Fig. 1) that contains the thiophenolate and amine donors instead of phenolate donors [19]. DBT complex is stable under physiological conditions, but, it is characterized by low solubility. Therefore, we prepared DBT-CS nanoparticles (DBT-CSNPs) by loading DBT on chitosan nanoparticles to improve bioavailability and the therapeutic efficacy of DBT [20]. Chitosan, a natural biomaterial, is a modified biopolymer, derived by partial deacetylation of chitin. It has been investigated for numerous biomedical applications due to its biodegradability, biocompatibility, antimicrobial properties, and functionality [21]. Further, chitosan nanoparticles (CSNPs) have the advantages of chitosan and the properties of nanoparticles such as surface and interface effect, small size and quantum size effects. Therefore, chitosan nanoparticles are greatly studied as nanocarriers for drug, protein, and gene delivery systems [22, 23]. Our previous studies revealed that DBT and DBT-CSNPs have antibacterial and cytotoxic activities and can bind with the DNA helix via groove binding [20]. Therefore, in this study, and for the first time, the LD50 values of DBT and DBT-CSNPs were determined as well as their therapeutic effects were evaluated against $\mathrm{CCl}_{4}$-induced liver injuries. The study focused on the determination of the markers of OS, apoptosis, liver functions, lipid profile, and kidney functions besides liver histopathology were determined. Additionally, the effect of DBT and DBT-CSNPs on cell cycle analysis in normal liver (THLE2) and human liver cancer (HepG2) cell lines were investigated to recognize if these compounds have antitumor activity.

\section{Results And Discussion}

The results showed that the prepared DBT-CSNPs have a spherical morphology with an average particle size of $\sim 85 \pm 2 \mathrm{~nm}$. The presence of DBT in the DBTCSNPs was found to increase the thermal stability of the composite material in comparison to DBT [20].

\subsection{LD50 of DBT and DBT-CS NPs}

The current results showed that LD50 values of DBT and DBT-CSNPs were about $1350 \mathrm{mg} / \mathrm{Kg}$ and $1800 \mathrm{mg} / \mathrm{Kg}$, respectively (Table 2). The previous results revealed that the LD50 values of oral titanium tetrachloride and oral titanium oxide nanoparticles $\left(\mathrm{TiO}_{2} \mathrm{NPs}\right)$ are $1780 \mathrm{mg} / \mathrm{kg}$ and greater than $12 \mathrm{~g} / \mathrm{kg}$, respectively[24].

\subsection{Effect of treatments with DBT, DBT-CS NPs and cisplatin on $\mathrm{CCl}_{4}$-induced hepatotoxicity}

\subsubsection{Effect of different studied compounds on OS}

The present results revealed that $\mathrm{CCl}_{4}$ injection caused a significant elevation $(P<0.05)$ in the malondialdehyde (MDA) level and GR activity, with a significant decline $(P<0.05)$ in the level of reduced glutathione (GSH) and the activities of glutathione-S-transferase (GST), total glutathione peroxidase (GPx) and superoxide dismutase (SOD) as compared with the control group (Fig. 3). MDA is the main product of peroxidation of polyunsaturated fatty acids and elevated MDA content is a significant indicator for the lipid peroxidation [25]. The formation of lipid peroxides in the liver tissues may be related to the effect of reactive free radicals of $\mathrm{CCl}_{4}$ metabolites, ' $\mathrm{CCl}_{3}$ and $\mathrm{CCl}_{3} \mathrm{OO}$ ', that accelerated the peroxidation of native membrane lipids. The elevation in the peroxidation of the mitochondrial membrane increased membrane permeability and altered calcium homeostasis, resulted in the loss of cell integrity that contributed to cell death $[5,6]$. On the other hand, free radical scavengers are nonenzymatic as GSH and enzymatic such as GPx, glutathione reductase (GR), GST and SOD could

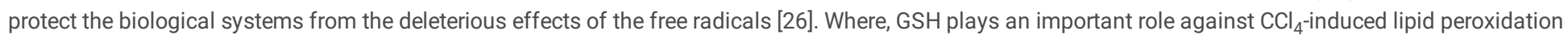
by covalently binding to ${ }^{\circ} \mathrm{CCl}_{3}$ and $\mathrm{CCl}_{3} \mathrm{OO}$ "radicals[27]. Additionally, $\mathrm{GSH}$ acts as a cofactor for GPx and as a nucleophilic scavenger of numerous compounds [26]. The depletion in $\mathrm{GSH}$ level after $\mathrm{CCl}_{4}$ administration could contribute to the stimulation of lipid peroxidation [1, 27]. Otherwise, GR plays a key role in cellular defense against OS by preventing the accumulation of oxidized glutathione (GSSG) and thus maintaining the redox state. The increase in GR activity after $\mathrm{CCl}_{4}$ administration possibly reflects an adaptation to oxidative condition and this agreed with previous studies [1, 2, 28]. Additionally, SOD is the first line of protection in the body against superoxide radicals [25]. SOD catalyzes the dismutation of the superoxide radical into ordinary molecular oxygen and $\mathrm{H}_{2} \mathrm{O}_{2}$. GPx, a selenium-containing enzyme, is the second line of protection against hydroperoxides through catalyzing the reduction of $\mathrm{H}_{2} \mathrm{O}_{2}$ and lipid peroxides, in the presence of GSH, to water and lipid alcohols, respectively, while GSH is transformed into GSSG [1, 27]. Otherwise, GSTs are major phase II detoxification enzymes found mainly in the cytosol. They catalyze the conjugation of GSH to a wide range of electrophilic substrates, usually resulting in detoxification. Subsequently, the reduction in the activities of antioxidant enzymes may be related to their inhibition by $\mathrm{CCl}_{4}$ and its reactive metabolites through direct interaction with the enzyme molecules. Also the inhibition of GPx and GST activities probably due to GSH depletion. SOD inhibition may be concerned with the oxidation of cysteine residues in the enzyme molecules by superoxide radicals and $\mathrm{H}_{2} \mathrm{O}_{2}[3,29]$. 
On the other hand, treatment with DBT and DBT-CSNPs after $\mathrm{CCl}_{4}$ injection increased MDA level (non-significantly) and GR activity (significantly: $\left.P<0.05\right)$ but decreased significantly the antioxidants (GSH level, GPx, GST and SOD activities) as compared to the $\mathrm{CCl}_{4}$ group (Fig. 2). This indicates that DBT and DBTCSNPs increased non-significantly lipid peroxidation in liver tissues, in spite of, they improved the malfunctioning liver and kidney functions, and lipid profile as mentioned in (Table 3). The results clarify that DBT and DBT-CSNPs deteriorated the unwanted hepatocytes via non significant oxidative stress. The induction of OS may be related to the effect of DBT and DBT-CSNPs and their metabolites, $\mathrm{TiO}_{2}$ and $\mathrm{TiO}_{2} \mathrm{NPs}$, respectively. TiO ${ }_{2}$ induces the generation of ROS such as $\mathrm{O}_{2}-\mathrm{H}_{2}$ and $\mathrm{H}_{2} \mathrm{O}_{2}$, resulting in increasing oxidative stress, lipid peroxidation, membrane damage, and increases the apoptosis of the unwanted cells [30]. Also, the thiol groups in the DBT and DBT-CSNPs are able to oxidize in the presence of $\mathrm{H}_{2} \mathrm{O}_{2}$, forming O-S-O [31] resulting in the reduction of $\mathrm{H}_{2} \mathrm{O}_{2}$ and this leads to the non-significant elevation in the MDA level compared with $\mathrm{CCl}_{4}$. Moreover, the reduction in the antioxidant enzymes may be related to the fact that SOD and GPx are Zn- and selenium-dependent enzymes, respectively. Therefore their inhibition may be due to the replacement of zinc and selenium by Ti. Also, the reduction of GSH level may be due to the binding of Ti with the sulfhydryl group and accordingly decreasing GPx and GST activities[32]. These results indicate that DBT and DBT-CSNPs may promote its antineoplastic effect, though the induction of the oxidative stress, which in consistence with the action of antineoplastic drugs, including doxorubicin and cyclophosphamide [33, 34]

The results showed that the treatment with CSNPs after $\mathrm{CCl}_{4}$ injection increased non-significantly MDA level and GR activity (Fig. 3). While this treatment decreased significantly the antioxidant parameters as compared to the $\mathrm{CCl}_{4}$ group (Fig. 3). Also, Fig. 3 shows that the administration of CSNPs, DBT-CSNPs and DBT to healthy rats for 14 days caused non-significant changes (increases or decreases) in the levels of markers of lipid peroxidation and the antioxidant markers compared with the control group. This led to nonsignificant changes in the markers of lipid profile, liver and kidney functions. In general, the results revealed that DBT-CSNPs had a greater effect than DBT and this may be due to the physicochemical properties of the nanoparticles which is distinguished by nano- size, raised surface area/unit mass and surface property effects that facilitated its passage through the cellular membranes, hydrolyzed into $\mathrm{TiO}_{2} \mathrm{NPs}$ and interrupted the biological systems [35-38]. Our results are in agreement with the studies which showed that the nanoparticles as CSNPs induce OS and this process is in a dose-dependent manner $[39,40]$. Therefore, DBT and DBT-CSNPs must not be taken without medical indications and must be taken for a short period.

Otherwise, Fig. 3 reveals that treatment with cisplatin (for 4 days) after $\mathrm{CCl}_{4}$ injection significantly increased OS as shown from the elevation of lipid peroxidation and reduction of antioxidant parameters leading to liver damage resulting in the elevation of serum liver enzymes and changing the lipid profile [41-43].

\subsubsection{Effect of different studied compounds on apoptosis}

Apoptosis is a basic biochemical process for a selective and controlled removal of cells within multicellular organisms and a key mechanism for the elimination of injured, infected, or mutated cells [44-46]. Apoptosis is tightly regulated by specific genes, including several pro-and anti-apoptotic proteins [44, 45]. Proteins of the Bcl-2 family exert different effects; for example, Bcl-2 and $\mathrm{Mcl}-1$ are anti-apoptotic proteins, while white B-cell lymphoma X protein (bax, Bad and Bak) exhibit pro-apoptotic effects. Dysfunction of apoptosis renders the cancer cell resistant to treatment as well as promotes the tumorigenesis [45, 47]. Bax activation elicits cytochrome-c release, procaspase-3 activation and Poly (ADP-ribose) polymerase cleavage through the stimulation of Apaf- 1 (apoptosis protease activating factor-1) which leads to the induction of the apoptotic response and cell death [48]. Caspase-8 is a cysteine protease that initiates apoptotic signaling via the extrinsic pathway. Activation of caspase-8 induces apoptosis through the direct activation of caspase-3 or activation of Bax which in turn activates caspase-3. These activations led to the cleavage of essential substrates for cell viability, inducing cell death [48, 49]. Additionally, cleavage of chromosomal DNA into oligonucleosomal size fragments is an essential part of apoptosis [44-46].

The current results revealed that $\mathrm{CCl}_{4}$ administration showed a significant $(P<0.05)$ down-regulation of $\mathrm{Bcl} 2$ expression with a significant $(P<0.05)$ upregulation of Bax and caspase-8 expressions as well as reduction in DNAF level compared to the control group (Fig. 4a, b and c "lane 1"). Furthermore, a significant $(\mathrm{P}<0.05)$ elevation was observed in the ratio of $\mathrm{Bax} / \mathrm{Bcl}-2$. This indicates that $\mathrm{CCl}_{4}$ administration induced apoptosis where the elevation in $\mathrm{Bax} / \mathrm{Bcl}-2$ ratio caused a change in the integrity of the mitochondrial membrane leading to cytochrome $\mathrm{C}$ release to the cytoplasm. Where cytochrome $\mathrm{C}$ binds to the Apaf- 1 resulting in the activation of procaspase 9 which in turn activate procaspases- 3 and 7 leading to apoptosis and the cell death[4, 50]. Moreover, as shown from the current results, the elevation in caspase-8 after $\mathrm{CCl}_{4}$ administration induced apoptosis. Where caspase- 8 activates caspase-3 (direct) or activates Bax, which in turn activates caspase-3 (indirect pathway) leading to the cleavage of the fundamental substrates for cell viability, inducing cell death $[4,50,51]$. Otherwise, as shown from our results, $\mathrm{CCl}_{4}$ increases the ROS, which plays an important role in the activation of apoptosis through intrinsic and extrinsic pathways. The elevation in ROS, leads to the increase of p53 signaling which in turn stimulates the Bax expression, but inhibits Bcl-2 expression[33, 34]. Moreover, DNAF and DNA damage may be related to the reaction of $\mathrm{CCl}_{4}$ metabolites (" $\mathrm{CCl}_{3}$ and $\mathrm{CCl}_{3} \mathrm{OO}{ }^{\circ}$ ) and other lipid peroxidation products with DNA forming adducts[1,2] that activated pro-apoptotic factors, promoting apoptosis and cell death [52]. Our results are in agreement with the previous studies which demonstrated that $\mathrm{CCl}_{4}$ induces rat liver fibrosis through the activation of apoptosis[4, 50, 51].

In contrast, treatment with DBT and DBT-CSNPs, and cisplatin after $\mathrm{CCl}_{4}$ injection caused a significant $(P<0.05)$ elevation in the Bcl-2 expression level associated with a significant $(P<0.05)$ decline in the expression levels of Bax and caspase-8 as well as reduction in the Bax/Bcl-2 ratio and DNAF level compared to the $\mathrm{CCl}_{4}$ group (Fig. 4a-c). Also, treatment with CSNPs after $\mathrm{CCl}_{4}$ injection caused a nonsignificant elevation in all markers of apoptosis when compared with the $\mathrm{CCl}_{4}$ group. This indicates that the treatment with DBT-CSNPs after $\mathrm{CCl}_{4}$ was related to the effect of DBT not to that of CSNPs. DBT, DBTCSNPs, and their metabolites as well as cisplatin reduced the apoptosis induced by $\mathrm{CCl}_{4}$. A possible mechanism for such effect is the reduction of Bax/Bcl2 ratio led to the stabilization of the mitochondrial membrane and prevented the releasing of cytochrome C. Interestingly, treatment with DBT-CSNPs showed a greater effect than DBT and this may be due to the differences in the physicochemical properties of these compounds and their metabolites as mentioned before. These results agree with the previous studies which showed that $\mathrm{TiO}_{2} \mathrm{NPs}$ have anti-apoptotic action greater than $\mathrm{TiO}_{2}$ [53]. Also, the studies showed that nanoparticles act as anti-apoptotic effect depending on their doses and period as well as cellular types [50].

Page $4 / 17$ 
Otherwise, treatment with DBT-CSNPs and DBT gave better results than cisplatin treatment. Where treatment with cisplatin (for 4 days) after CCl 4 injection significantly increased OS and lipid peroxidation leading to liver damage resulting in the elevation of serum liver enzymes and changing the lipid profile (Table 3) which in accordance with Silici [54] and Ateyya [55].

On the other hand, the administration of each DBT, DBT-CSNPs, or CSNPs for the healthy rats caused non-significant changes in all markers of apoptosis as compared with the control group (Figs. 3 and 4). This indicates that DBT-CSNPs and DBT have no effect on the apoptotic markers in normal animals.

\subsubsection{Liver and kidney functions and lipid profile}

The results showed that $\mathrm{CCl}_{4}$ administration caused significant $(P<0.05)$ elevation in the activities of serum ALT, AST and ALP with significant reductions in serum albumin and TP and liver TP levels compared to the control group (Table 3). Also, there were significant increases $(P<0.05)$ in serum cholesterol, TG and LDL-cholesterol with a significant decrease in serum HDL-cholesterol level (Table 3 ). This may be due to liver damage induced by $\mathrm{CCl}_{4}$ which led to the leakage of liver enzymes into the blood circulation and decreased protein biosynthesis [56]. Additionally, blood urea and serum creatinine levels in rats injected with $\mathrm{CCl}_{4}$ were significantly increased $(P<0.05$, Table 3$)$ indicating that $\mathrm{CCl}_{4}$ induced nephrotoxicity and these results are in accordance with the results of Safhi [57].

Otherwise, treatment with DBT and DBT-CSNPs after $\mathrm{CCl}_{4}$ administration improved liver functions, lipid profile and kidney functions with different degrees as shown from the levels of all parameters (Table 3). This indicates that treatment with DBT and DBT-CSNPs reduced the hepato-and nephrotoxicity induced by $\mathrm{CCl}_{4}$. Also, treatment with DBT-CSNPs showed a better effect than DBT. Treatment with $\mathrm{CSNPs}$ after $\mathrm{CCl}_{4}$ administration caused nonsignificant changes in all markers of liver and kidney functions and lipid profile.

Treatment with cisplatin after $\mathrm{CCl}_{4}$ administration improved liver function and lipid profile, but to a lesser degree than those treated with DBT and DBT-CSNPs (Table 3). Furthermore, cisplatin treatment caused non-significant improvement in kidney functions compared to the $\mathrm{CCl}_{4}$ group. These results agree with the previous studies which showed that treatment of different cancers with cisplatin causes nephro-, neuro-, cardio- and hepatotoxicity, due to its accumulation in the liver, kidney and other organs leading to production of ROS and induces OS resulting in kidney failure and liver damage [71].

On the other hand, Table 3 shows that DBT and DBT-CSNPs administration for the healthy rats for 14 days caused significant changes $(\mathrm{P}<0.05)$ in some markers of liver and kidney functions and lipid profile as compared to the control group. These effects on healthy rats may be related to the long period (14 days) of the administration of DBT and DBT-CSNPs and the accumulation of their metabolites. The results showed that CSNPs administration to healthy rats for 14 days caused nonsignificant changes in liver and kidney functions and lipid profile as compared to the control group.

\subsubsection{Histopathological analysis}

The histopathological characteristics of liver tissues from the different studied groups are shown in Fig. 5 (A-K). Administration of the healthy rats with each CSNPs, DBT and DBT-CSNPs, separately had no effect on normal liver architecture. While, treatment with DBT and DBT-CSNPs after CCI4 administration improved liver histopathology induced by CCI4 indicating the therapeutic roles of DBT and DBT-CSNPs that confirm the biochemical analysis.

\subsection{BT and DBT-CSNPs toxicity and cell cycle arrest}

The viability of the HepG2 and THLE2 cells was measured under the effect of different concentrations of each DBT and DBT-CSNP for $24 \mathrm{~h}$ (Fig. $6 \mathrm{a}$ ). The results showed that the cell viability of HepG2 and THLE2 cells was decreased with increasing the concentration of these compounds. Also, both DBT and DBT-CSNP showed selective cytotoxic, where DBT-CSNP exhibits greater cytotoxicity against HepG2 cells than DBT cytotoxicity (their IC50 values were 44.04 and $31.76 \mu \mathrm{g} / \mathrm{ml}$, respectively). While, DBT-CSNP exhibits lower cytotoxicity towards the normal THLE2 cells than DBT cytotoxicity (their IC50 values were 1915 and $2094 \mu \mathrm{g} / \mathrm{ml}$, respectively).

Cell growth and proliferation are controlled by the cell cycle regulation, and an imbalance between them causes apoptosis that is implicated in the growth and progression of most tumors [58]. Therefore, anticancer agents that interfere with the cell division and halt the uncontrolled proliferation of cancer cells are considered an important treatment strategy $[58,59]$. The current results showed that treatment with DBT and DBT-CSNPs caused a significant decrease in the population of HepG2 cells in G0/G1 and S phases compared to the normal cells (Fig. 6b). High populations of HepG2 cells were arrested at G2/M checkpoint as compared to untreated cells. Also, the results showed that the cells treated with DBT-CSNPs showed the lowest levels of G0/G1 and S phases and the highest level of G2/M phase (Fig. 6b). Cell cycle arrest in the G2/M phase leads to disruption of the tubulin-microtubule equilibrium and allows the time for the repair of DNA damage [60]. This means that these complexes have anticancer activities and this may be related to the effect of the DBT and DBT-CSNPs and their hydrolyzates; $\left(\mathrm{TiO}_{2}\right.$ and $\left.\mathrm{TiO}_{2} \mathrm{NPs}\right)$, respectively. It has been reported that $\mathrm{TiO}_{2} \mathrm{NPs}$ may induce OS in HepG2 cellscausing DNAF and p53 activation which lead to apoptosis [30,37]. The results also indicate that each DBT and DBT-CSNPs inhibited cell growth in S- and G2/M-phases with different degrees and DBT-CSNPs has a potent effect than DBT, this may be due to the simplicity of these NPs which can pass throughout the cellular membranes and disturb the biological systems.

In general, our results revealed that DBT-CSNPs and DBT treatments decreased rat liver apoptosis induced by $\mathrm{CCl}_{4}$ resulting in the improvement of liver architecture and functions.

In contrast, the results showed that DBT-CSNPs and DBT prevented the proliferation of the HepG2 cell line, where they arrested the cell cycle in the G2/M phase. Also, these compounds showed pro-apoptotic effects in HepG2 cells. These results indicate that both complexes are characterized by selectivity, i.e. they have an ability to differentiate between liver injuries and cancer cell lines. These results are in agreement with the previous studies which reported that the effect of some drugs and xenobiotics are not matched in vivo and in cell lines $[67,68]$. These results are in agreement with the previous studies which reported that the effect of some drugs and xenobiotics in vivo and in cell lines are unlike each other [61, 62]. Where, these studies revealed that tumor cell lines have 
important limits, and there are some variations between cell lines and tumor tissues in vivo including gene expression. Also, Cell lines lack interactions with the other cell types, their growth is not affected by cytokines and other cell signaling molecules, and the native tissue architecture is lost [61, 62].

\section{Conclusion}

LD50 values of DBT and DBT-CSNPs are $1350 \mathrm{mg}$ and $1800 \mathrm{mg}$, respectively. DBT and DBT-CSNPs have a therapeutic effect against CCl ${ }_{4}$-induced liver injuries by reducing apoptosis through the reduction of DNAF, caspase 8 , and the Bax/Bcl2 ratio as well as remediation of the antioxidant parameters. DBTCSNPs "due to their structure" have a greater effect than DBT and both compounds have greater effects than cisplatin. The administration of healthy rats with low doses of DBT and DBT-CSNPs for 14 days has no effect on apoptotic markers and non-significant effect on the oxidative stress. Otherwise, DBT and DBTCSNPs have antineoplastic activities against the HepG2 cell line, but DBT-CSNPs has a greater effect due to their nanostructure. Therefore, the pharmacokinetics of DBT-CSNPs and DBT should be evaluated to know their pharmacological roles.

\section{Materials And Methods}

\subsection{Chemicals}

Adherent HepG2 were obtained from the American Type Culture Collection (ATCC, Manassas, Virginia, USA). GIBCO® Minimum Essential Medium (MEM), was purchased from GIBCO, USA. Dulbecco's Phosphate Buffered Saline medium and L-glutamine were obtained from Invitrogen, USA. Trypsin-EDTA, penicillin and streptomycin were purchased from Thermo Fisher Scientific, USA. Cisplatin, $\mathrm{CCl}_{4}$, dimethylsulfoxide (DMSO) and other analytical grade chemicals were purchased from Sigma Aldrich, USA. MTT assay kit and RNA extraction kit were obtained from Eugene, Oregon, USA and Thermo Scientific, Fermentas, respectively. All other analytical grade chemicals were obtained from Sigma (Germany) and Merck (Germany). All dilutions were made with high purity deionized water, obtained from a Milli-Q® system (Merck Chemicals $\mathrm{GmbH}$, Darmstadt, Germany).

\subsection{Animals}

One hundred and twenty Sprague Dawley rats weighing 100-150 g were obtained from Faculty of Medicine, Alexandria University. The animals were housed in stainless cages under standard laboratory conditions of $12 \mathrm{~h}$ light/dark cycle, $55 \pm 5 \%$ air humidity at room temperature of $22 \pm 3{ }^{\circ} \mathrm{C}$ and received a standard laboratory diet and tap drinking water for 2 weeks, as an adaptation period. All animal methodology was accomplished following the Institutional Animal Care and Use Committee (IACUC) and approved via the Committee of the Animal Care and Use in Alexandria University (Ethical approval reference number: AU 04 $200620202)$.

\subsection{Preparation of DBT-CSNPs}

DBT-CSNPs were prepared from DBT, sodium tripolyphosphate and chitosan[20]. In brief, sodium tripolyphosphate solution was added to chitosan solution, left at $25^{\circ} \mathrm{C}$ for 12 hours, DBT was added, left for $40 \mathrm{~min}$ and the solvent was removed at $40^{\circ} \mathrm{C}$. The characterization of DBT-CSNPs was examined by High Resolution Transmission Electron Microscope (HR-TEM), Scanning Electron Microscope (SEM) with EDX detector, X-Ray Diffraction (XRD), Fourier transforms infrared (FT-IR) and thermographymetric analysis (TGA) [20].

\subsection{Determination of LD50 values of DBT and DBT-CSNPs}

For determination of LD50 of DBT or DBT-CSNPs, 48 rats were used. The animals were divided into 12 groups and six doses of each DBT or DBT-CSNPs dissolved in $2 \%$ DMSO $(200,400,800,1200,2000$ and $3000 \mathrm{mg} / \mathrm{kg})$ were used for the administration once, intraperitoneally (i.p). The animals were examined for any abnormal clinical signs and behavioral changes for $24 \mathrm{~h}$. The number of dead rats in each group was recorded (\% dead) and $L D_{50}$ was calculated by the arithmetic method of Kärber [63]

$$
L D 50=L D 100-\sum(a \times b) / n
$$

LD100 = Lethal dose causing the $100 \%$ mortality

$\boldsymbol{n}=$ Group population: total number of animals/ group.

$\boldsymbol{a}=$ Dose difference: the difference between two successive doses of the administered substance.

$\boldsymbol{b}=$ Mean mortality: the average number of dead animals in two successive doses.

\subsection{Biological effects of DBT, DBT-CSNPs and cisplatin on $\mathrm{CCl}_{4}$-induced hepatotoxicity}

The doses of DBT and DBT-CSNPs were chosen to be safe, away from their LD50 values where these doses approach that of cisplatin. DBT and DBT-CSNPs and CSNPs were dissolved in $2 \%$ DMSO $[64,65]$. Seventy two Sprague Dawley rats were divided into nine groups (8 animals/group).

Fig. 2 shows the experimental design, since the period of the experiment was 12 weeks comprehensive 2 weeks the adaptation period. Control group (C): the rats were treated with $0.5 \mathrm{ml}$ DMSO (2\%) for 14 days (at 9th and 10th weeks), CSNPs group: the rats were treated (i.p) with 3.0 mg CSNPs / kg BW/day for 14 days (at 9th and 10th weeks), DBT group: the rats were treated (i.p) with DBT (4.5 mg/kg BW/day for 14 days (at 9th and 10th weeks), DBT-CSNPs group: the rats were treated (i.p) with DBT-CSNPs $\left(3.0 \mathrm{mg} / \mathrm{kg} \mathrm{BW} /\right.$ day for 14 days (at 9 th and 10 th weeks), $\mathbf{C C l}_{4}$ group: the rats were injected (i.p) with $0.5 \mathrm{ml}$ of $99.9 \%$ 
$\mathrm{CCl}_{4} / \mathrm{kg} \mathrm{BW}$, with equal amount of olive oil, day after day for 6 weeks (at $3^{\text {rd }}$ and $8^{\text {th }}$ weeks) [66]. CCl ${ }_{4}-\mathrm{CSNPs}_{1} \mathrm{CCl}_{4}$-DBT, CCl ${ }_{4}$-DBT-CSNPs groups: the rats were injected with $\mathrm{CCl}_{4}$ for 6 weeks, then they treated with the same doses and periods of CSNPs, DBT and DBT-CSNPs, respectively. CCl ${ }_{4}$ - Cisplatin: the rats were injected with $\mathrm{CCl}_{4}$ for 6 weeks then they treated (i.p.) with $4 \mathrm{mg}$ of cisplatin/kg BW/day for 5 consecutive days [67]. At the end of the experimental period, the rats were fasted overnight and sacrificed after anesthetized by carbon dioxide. Blood was collected from caudal vena cava, kept at room temperature for 15 $\mathrm{min}$, then centrifuged at $3000 \mathrm{rpm}$ for $10 \mathrm{~min}$ and serum was stored at $-20^{\circ} \mathrm{C}$ until used. The livers were removed immediately where small portions were taken and fixed in $10 \%$ formalin for the histopathological examination. The remaining livers were washed with cold saline solution ( $0.9 \% \mathrm{NaCl})$, divided into two parts and kept at $-80^{\circ} \mathrm{C}$. The first part was used for determination of the expression levels of caspase-8, Bcl-2, Bax and DNA fragmentation (DNAF). The second part was homogenized in 9 volumes of cold $0.1 \mathrm{M}$ sodium phosphate buffer ( $\mathrm{pH} 7.4$ ) containing $0.9 \% \mathrm{NaCl}$, using a glass-Teflon Homogenizer and the homogenate was centrifuged at $4000 \mathrm{rpm}$ for $15 \mathrm{~min}$ at $4^{\circ} \mathrm{C}$. The supernatant was kept, at $-80^{\circ} \mathrm{C}$ till used for determination of the markers of $0 \mathrm{~S}$ [malondialdehyde (MDA) and reduced glutathione (GSH) levels, and the activities of glutathione-S-transferase (GST), total glutathione peroxidase (GPx), glutathione reductase (GR) and superoxide dismutase (SOD)].

\subsubsection{Effect of the studied compounds on OS markers}

The level of malondialdehyde (MDA, as oxidant) and the antioxidants \{GSH and the activities of GPx (EC 1.11.1.19), GR (EC 1.8.1.7), GST (EC 2.5.1.18) and SOD (EC 1.15.1.1)\}were determined according to the methods of Ohkawa [68] Ellman [69], Rotruck [70], Bergmeyer [71], Habig [72] and Marklund and Marklund [73], respectively.

\subsubsection{Effect of the studied compounds on apoptotic markers}

\subsubsection{Determination of gene expressions of $\mathrm{Bcl} 2$, Bax and caspase- 8}

Total RNA was isolated from liver tissues using the RNA extraction kit (Thermo Scientific, Fermentas, \#K0731). Total RNA was quantified using a NanoDrop ${ }^{\text {TM }}$ Q5000 (UV-Vis spectrophotometer Q5000/USA). The complementary DNA was produced using reverse transcription kits (Thermo Scientific, Fermentas, \#EP0451). The synthesized cDNA was amplified using 2X Maxima SYBR Green/ROX qPCR Master Mix (Thermo scientific, USA, \# K0221). The primers for Bax, $\mathrm{Bcl} 2$, caspase- 8 and $\beta$-actin are listed in Table 1. RT-PCR cycle parameters included $10 \mathrm{~min}$ at $95^{\circ} \mathrm{C}$ followed by 40 cycles involving the denaturation at $95{ }^{\circ} \mathrm{C}$ for $15 \mathrm{~s}$, annealing at $60^{\circ} \mathrm{C}$ for $30 \mathrm{~s}$ and elongation at $72^{\circ} \mathrm{C}$ for $30 \mathrm{~s}$, then final elongation at $72^{\circ} \mathrm{C}$ for 5 min. qRT-PCR was performed using StepOnePlus ${ }^{\mathrm{TM}}$ RealTime PCR System (Applied Biosystems, Life technology, USA). A division curve program was employed after each reaction in order to verify the purity of the PCR products. The quantities critical threshold (Ct) of target gene was normalized with quantities (Ct) of housekeeping gene ( $\beta$-actin) by using the $2^{-\Delta \Delta C t}$ method to calculate the fold change in target gene.

\subsubsection{Determination of DNAF}

It was determined using agarose gel electrophoresis technique [74]. Liver tissues were homogenized in five volumes of $50 \mathrm{mM}$ Tris-HCl buffer containing 50 mM EDTA and $20 \%$ sucrose, pH 7.6. The genomic DNA was separated using the DNA purification kit (G-spin ${ }^{\mathrm{TM}}$ Total, Cat. No.17045, Korea). Then $15 \mu \mathrm{g}$ of DNA/lane was loaded and separated by electrophoresis for $2 \mathrm{~h}$ on $1 \%$ agarose gel containing ethidium bromide $(10 \mu \mathrm{g} / \mathrm{ml})$. Finally, the DNA bands were visualized using trans-illumination with ultraviolet light (Consort, Turnhout, Belgium).

\subsubsection{Effect of the studied compounds on liver and kidney functions and lipid profile}

Liver biomarkers involving; serum AST (EC 2.6.1.1), ALT (EC 2.6.1.2) and ALP (EC 3.1.3.1) activities, serum total protein (TP) and albumin and liver total protein levels were assayed using commercial kits (Biosystem, S.A., Spain). Lipid profile (serum triglycerides, cholesterol, HDL and LDL levels) and kidney markers (urea and creatinine levels) were determined using kits (Biosystem, S.A., Spain).

\subsubsection{Liver histopathological analysis}

Liver tissues were fixed, processed and embedded in paraffin wax. Sections of $5 \mu \mathrm{m}$ in thickness were cut and stained with hematoxylin and eosin (H \& E) for examination using light microscope [75].

\subsection{Disclosure of the antitumor activities of DBT and DBT-CSNPS}

\subsubsection{Cell viability}

The anti-proliferative activity of the DBT and DBT-CS nanocomposite was studied against HepG2 and THLE2 cell lines using methyl thiazolyl tetrazolium (MTT) assay. MTT assay isused to quantify the number of viable cells, depends on the reduction of the yellow tetrazolium salt MTT to a purple MTT-formazan crystal by viable cells with active metabolism [76]. HepG2 and THLE2 Cells were plated in 96-well plates at $10^{4}$ cells/well and treated after $24 \mathrm{~h}$ with serial dilutions $(0,3.125,6.25,12.5,25,50,100$ and $200 \mu \mathrm{g} / \mathrm{ml} \mathrm{DMSO}(0.1 \%)$ of DBT and DBT-CS nanocomposite separately. Each concentration was repeated in 4 wells. After incubation, $10 \mu \mathrm{L}$ of MTT solution $(5 \mathrm{mg} / \mathrm{ml})$ in phosphate- buffered saline (PBS) was added to each well and incubated for another $4 \mathrm{~h}$ at $37{ }^{\circ} \mathrm{C}$. After the medium was discarded, $100 \mu \mathrm{L}$ of DMSO was added to each well to dissolve the purple formazan crystal formed at the bottom of the wells. Absorbance at $490 \mathrm{~nm}$ was measured in a BioTek Instruments Elx800 Universal Microplate Reader (USA) and the percentage of cell inhibition was determined.

\subsubsection{Cell cycle analysis}

The distribution of HepG2 cells in the different cell cycle phases (G0/G1, S and G2/M) were estimated [77]. Briefly, HepG2 cells were untreated (control, reseived only DMSO, $0.1 \%$ ) and treated with $40 \mu \mathrm{g} / \mathrm{ml}$ of DBT and DBT-CSNPs separately for $24 \mathrm{~h}$, then cells were harvested and fixed in ice cold $70 \%$ ethanol 
at $4{ }^{\circ} \mathrm{C}$ for 12 hours and centrifuged at $1000 \mathrm{rpm}$ for $5 \mathrm{~min}$. The pellets were resuspended in $\left.0.05 \mathrm{mg} / \mathrm{ml} \mathrm{propidium} \mathrm{iodide} \mathrm{(} 0.05 \mathrm{mg} / \mathrm{ml}\right)$ and RNase ( 100 $\mathrm{U} / \mathrm{ml}$ ) in phosphate buffer ( $\mathrm{pH} 7.4$ ), incubated at $37^{\circ} \mathrm{C}$ for $30 \mathrm{~min}$ and DNA was analyzed by flow cytometer (Attune ${ }^{\circledR}$ acoustic focusing flow cytometer, Thermo Scientific, USA). Finally, cellquest software was used to analyze the cell cycle data.

\subsection{Statistical analysis}

The data were expressed as means \pm SD (standard deviation). One-way analysis of variance (ANOVA) using SPSS, 18.0 Software, 2011 and the individual comparisons were acquired by Duncan's multiple range test (DMRT). Values were considered statistically significant when $P<0.05$.

\section{List Of Abbreviations}

ALP: alkaline phosphatase; ALT: alanine aminotransferase; Apaf-1: apoptosis protease activating factor-1; AST: aspartate aminotransferase; $\mathrm{CCl}_{4}$ : carbon tetrachloride; CSNPs: chitosan nanoparticles; DBT: dithiophenolato titanium (IV); DBT-CSNPs: : dithiophenolato titanium (IV)- chitosan nanoparticles; DMSO: dimethylsulfoxide; DMRT: Duncan's multiple range test; DNAF: DNA-fragmentation; EDTA: ethylenediamine-tetraacetic acid; GPx: glutathione peroxidase; GR: glutathione reductase: GSH: reduced glutathione; GSSG: oxidized glutathione; GST: glutathione-S-transferase; $\mathrm{H}_{2} \mathrm{O}_{2}$ : hydrogen peroxide; $\mathrm{HDL}$ : high density lipoprotein; HepG2: human hepatoma G2; LD50; lethal dose causing the 50\% mortality; LD100: lethal dose causing the $100 \%$ mortality; LDL: low density lipoprotein; MDA: malondialdehyde; MTT: methyl thiazolyl tetrazolium; OS: oxidative stress; RNS: reactive nitrogen species; ROS: reactive oxygen species; SOD: superoxide dismutase; TG: triacylglycerol; $\mathrm{Ti}(\mathrm{IV})$ :titanium; $\mathrm{TiO}_{2}$ : titanium oxide; $\mathrm{TiO}_{2} \mathrm{NPs}$ : titanium oxide nanoparticles; TP: total protein.

\section{Declarations}

\section{Authors' contributions}

Nadia Z.Shaban suggested this study, designed and organization and participated in the sequence arrangement, wrote and reviewed and approved manuscript, and agreement to be accountable for all aspects of the work to be accountable for all aspects of the work for ensuring that questions related to the accuracy or integrity of any part of the work are appropriately investigated and resolved. Salah A. Yehia participated in the suggestion of this study, participated in its design, carried out the experimental part in vitro and in vivo, performed the statistical analysis and drew the figures, and was a major contributor in writing and reviewing the manuscript. Doaa Awad participated in the statistical analysis. Shaban Y. Shaban participated in the supervision of the preparation of the studied complexes, read and approved the final manuscript. Samar R. Saleh participated in the suggestion of this study and its design, supervised on the experimental part and the statistical analysis, and contributed to writing and reviewing the manuscript.

\section{Author details}

Nadia Z. Shaban ${ }^{1 *}$, Salah A. Yehia ${ }^{1}$, Doaa Awad ${ }^{1}$, Shaban Y. Shaban ${ }^{2}$, Samar R. Saleh ${ }^{1}$

${ }^{1}$ Biochemistry Department, Faculty of Science, Alexandria University, Alexandria, Egypt

${ }^{2}$ Chemistry Department, Faculty of Science, Kafrelsheikh University, 33516 Kafrelsheikh, Egypt

\section{Acknowledgements}

The authors thank Dr. Kamel R. Shoueir (Institute of Nanoscience \& Nanotechnolsogy, Kafrelsheikh University, Egypt) for participation in the preparation of the studied complexes in the form of nanoparticles. Also, the authors thank Dr. Ahmed Alaa Abdul-Aziz, Department of Endocrinology, Faculty of Medicine, Alexandria University, for his participation in the histological examination of the liver.

\section{Competing interests}

All authors have no conflicts of interest.

\section{Availability of data and material}

All data generated or analyzed during this study are included in this published article.

\section{Funding}

The authors declare that there is no funding for this research

\section{Ethical conduct of research}

All animal procedures were carried out in accordance with the Ethics Committee of the Faculty of Science, Alexandria University, where we have obtained institutional review board approval from Alexandria University for the research described (Approval No. AU 04200620202 ).

\section{References}

1. Shaban, N.Z., et al., Effect of Punica granatum (pomegranate) juice extract on healthy liver and hepatotoxicity induced by diethylnitrosamine and phenobarbital in male rats. J Med Food, 2014. 17(3): p. 339-49. 
2. Al-Seeni, M.N., et al., The hepatoprotective activity of olive oil and Nigella sativa oil against CCl (4) induced hepatotoxicity in male rats. BMC complementary and alternative medicine, 2016. 16(1): p. 438-438.

3. Abdel-Monem, N.M., et al., Exopolysaccharide-peptide complex from oyster mushroom (Pleurotus ostreatus) protects against hepatotoxicity in rats. Biochemistry and Biophysics Reports, 2020. 24: p. 100852.

4. Liu, Y., et al., Breviscapine ameliorates CCl4-induced liver injury in mice through inhibiting inflammatory apoptotic response and ROS generation. International journal of molecular medicine, 2018. 42 (2): p. 755-768.

5. Wang, Y., C. Tang, and H. Zhang, Hepatoprotective effects of kaempferol 3-O-rutinoside and kaempferol 3-O-glucoside from Carthamus tinctorius L. on CCl4-induced oxidative liver injury in mice. J Food Drug Anal, 2015. 23 (2): p. 310-317.

6. Dutta, S., et al., Amelioration of CCl4 induced liver injury in swiss albino mice by antioxidant rich leaf extract of Croton bonplandianus Baill. PloS one, 2018. 13 (4): p. e0196411-e0196411.

7. Uchida, D., et al., Oxidative Stress Management in Chronic Liver Diseases and Hepatocellular Carcinoma. Nutrients, 2020. 12 : p. 1576.

8. Rashed, W.M., et al., Hepatocellular Carcinoma (HCC) in Egypt: A comprehensive overview. Journal of the Egyptian National Cancer Institute, 2020. 32 (1): p. 5 .

9. Marcellin, P. and B.K. Kutala, Liver diseases: A major, neglected global public health problem requiring urgent actions and large-scale screening. Liver Int, 2018. 38 Suppl 1: p. 2-6.

10. Ellahioui, Y., S. Prashar, and S. Gómez-Ruiz, Anticancer Applications and Recent Investigations of Metallodrugs Based on Gallium, Tin and Titanium. Inorganics, 2017. 5(1).

11. Zhang, P. and P.J. Sadler, Advances in the design of organometallic anticancer complexes. Journal of Organometallic Chemistry, 2017. 839: p. 5-14.

12. Frezza, M., et al., Novel metals and metal complexes as platforms for cancer therapy. Current pharmaceutical design, 2010.16 (16): p. $1813-1825$.

13. Tan, C.-P., et al., Metallomics insights into the programmed cell death induced by metal-based anticancer compounds. Metallomics, 2014. 6 (5): p. $978-$ 995.

14. Ananth, H., et al., A Review on Biomaterials in Dental Implantology. International journal of biomedical science: IJBS, 2015.11 (3): p. $113-120$.

15. Tshuva, E.Y. and M. Miller, Coordination Complexes of Titanium(IV) for Anticancer Therapy. Met lons Life Sci, 2018. 18.

16. Köpf-Maier, P. and R. Martin, Subcellular distribution of titanium in the liver after treatment with the antitumor agent titanocene dichloride. A study using electron spectroscopic imaging. Virchows Arch B Cell Pathol Incl Mol Pathol, 1989. 57 (4): p. 213-22.

17. Ganot, N., et al., In Vivo Anticancer Activity of a Nontoxic Inert Phenolato Titanium Complex: High Efficacy on Solid Tumors Alone and Combined with Platinum Drugs. ChemMedChem, 2018. 13(21): p. 2290-2296.

18. Meker, S., et al., Anti-proliferative activity of nano-formulated phenolato titanium(IV) complexes against cancer cells. ChemMedChem, 2014. 9(6): p. 12948.

19. Shaban, S.Y., A.E.-M.M. Ramadan, and F.W. Heinemann, Titanium isopropoxide complexes containing diamine bis-thiolato based [N2S2]2- ligands; effect of steric bulk on coordination features. Inorganic Chemistry Communications, 2012. 20: p. 135-137.

20. Shaban, N.Z., et al., Design, DNA binding and kinetic studies, antibacterial and cytotoxic activities of stable dithiophenolato titanium(IV)-chitosan Nanocomposite. Journal of Molecular Liquids, 2019. 287: p. 111002.

21. Samar, R.S., et al., Berberine Nanoencapsulation Attenuates Hallmarks of Scoplomine Induced Alzheimer's-Like Disease in Rats. Current Clinical Pharmacology, 2020. 15: p. 1-16.

22. Li, J., et al., Chitosan-Based Nanomaterials for Drug Delivery. Molecules (Basel, Switzerland), 2018. 23(10): p. 2661.

23. Hafez, H.S., et al., Neuroprotective effect of ipriflavone against scopolamine-induced memory impairment in rats. Psychopharmacology (Berl), 2017. 234(20): p. 3037-3053.

24. Wang, J., et al., Acute toxicity and biodistribution of different sized titanium dioxide particles in mice after oral administration. Toxicology letters, 2007. 168(2): p. 176-185.

25. Alkreathy, H.M., et al., CCl4 induced genotoxicity and DNA oxidative damages in rats: hepatoprotective effect of Sonchus arvensis. BMC Complement Altern Med, 2014. 14: p. 452.

26. Kurutas, E.B., The importance of antioxidants which play the role in cellular response against oxidative/nitrosative stress: current state. Nutrition journal, 2016. 15(1): p. 71-71.

27. Shah, M.D., U.J.A. D'Souza, and M. Iqbal, The potential protective effect of Commelina nudiflora L. against carbon tetrachloride (CCl4)-induced hepatotoxicity in rats, mediated by suppression of oxidative stress and inflammation. Environmental Health and Preventive Medicine, 2017. 22(1): p. 66.

28. Shaban, N.Z., et al., Effects of Bacillus thuringiensis toxin on hepatic lipid peroxidation and free-radical scavengers in rats given alpha-tocopherol or acetylsalicylate. Comparative Biochemistry and Physiology Part C: Toxicology \& Pharmacology, 2003. 135(4): p. 405-414.

29. Ighodaro, O. and O.A. Akinloye, First line defence antioxidants-superoxide dismutase (SOD), catalase (CAT) and glutathione peroxidase (GPX): Their fundamental role in the entire antioxidant defence grid. Alexandria Journal of Medicine, 2017. 54.

30. Jia, X., et al., The Potential Liver, Brain, and Embryo Toxicity of Titanium Dioxide Nanoparticles on Mice. Nanoscale Res Lett, 2017.12 (1): p. 478.

31. Shaban, S., et al., Oxidation of Ru-bound thiolate thioether and its NS4-ligand containing thiolate and thioether sulfur donors: Synthesis, characterization, and X-ray structures. Journal of Coordination Chemistry - J COORD CHEM, 2010. 63: p. 2812-2820.

32. Birben, E., et al., Oxidative stress and antioxidant defense. The World Allergy Organization journal, 2012. 5 (1): p. 9-19.

33. Yokoyama, C., et al., Induction of oxidative stress by anticancer drugs in the presence and absence of cells. Oncology letters, 2017.14 (5): p. $6066-6070$. 
34. Fong, C., Free radical anticancer drugs and oxidative stress: ORAC and CellROX-colorectal cancer cells by quantum chemical determinations. 2018.

35. Liu, S., et al., Oxidative stress and apoptosis induced by nanosized titanium dioxide in PC12 cells. Toxicology, 2010.267 (1-3): p. 172-7.

36. Pujalté, I., et al., Cytotoxicity and oxidative stress induced by different metallic nanoparticles on human kidney cells. Particle and fibre toxicology, 2011. 8 (1): p. 10.

37. El-Said, K.S., et al., Molecular mechanism of DNA damage induced by titanium dioxide nanoparticles in toll-like receptor 3 or 4 expressing human hepatocarcinoma cell lines. J Nanobiotechnology, 2014. 12: p. 48.

38. Faedmaleki, F., et al., Study of Silymarin and Vitamin E Protective Effects on Silver Nanoparticle Toxicity on Mice Liver Primary Cell Culture. Acta Medica Iranica, 2016. 54: p. 85-95.

39. Jiang, Y., et al., Chitosan nanoparticles induced the antitumor effect in hepatocellular carcinoma cells by regulating ROS-mediated mitochondrial damage and endoplasmic reticulum stress. Artificial Cells, Nanomedicine, and Biotechnology, 2019. 47 (1): p. 747-756.

40. Miethling-Graff, R., et al., Exposure to silver nanoparticles induces size-and dose-dependent oxidative stress and cytotoxicity in human colon carcinoma cells. Toxicology in Vitro, 2014. 28.

41. Pratibha, R., et al., Enzymatic studies of cisplatin induced oxidative stress in hepatic tissue of rats. Eur J Pharmacol, 2006. 53 (3): p. $290-3$.

42. Abouzeinab, N., Cytoprotective effect and antioxidant properties of silymarin on cisplatin induced hepatotoxicity in rats: A biochemical and histochemical study. International Journal of Cancer Research, 2013.9 (1): p. 9-23.

43. Katarina, R., et al., The Platinum(II) Complexes Induced Oxidative Stress of Isolated Rat Heart. Serbian Journal of Experimental and Clinical Research, 2017. 18 (2): p. 111-117.

44. Kale, J., E.J. Osterlund, and D.W. Andrews, BCL-2 family proteins: changing partners in the dance towards death. Cell Death \& Differentiation, 2018. 25 (1): p. 65-80.

45. Hassan, M., et al., Apoptosis and molecular targeting therapy in cancer. BioMed research international, 2014. 2014: p. $150845-150845$.

46. Liu, Z., et al., Direct Activation of Bax Protein for Cancer Therapy. Medicinal research reviews, 2016. 36 (2): p. 313-341.

47. Campbell, K.J. and S.W.G. Tait, Targeting BCL-2 regulated apoptosis in cancer. Open biology, 2018. 8 (5): p. 180002.

48. Pistritto, G., et al., Apoptosis as anticancer mechanism: function and dysfunction of its modulators and targeted therapeutic strategies. Aging, 2016. 8 (4): p. 603-619.

49. Kalkavan, H. and D.R. Green, MOMP, cell suicide as a BCL-2 family business. Cell Death Differ, 2018. 25 (1): p. 46-55.

50. Eltahir, H.M. and M.H. Nazmy, Esomeprazole ameliorates CCl4 induced liver fibrosis in rats via modulating oxidative stress, inflammatory, fibrogenic and apoptotic markers. Biomedicine \& Pharmacotherapy, 2018. 97: p. 1356-1365.

51. Guo, X.L., et al., Glycyrrhizic acid attenuates CCI/-induced hepatocyte apoptosis in rats via a p53-mediated pathway. World J Gastroenterol, 2013. 19 (24): p. 3781-91.

52. Roos, W.P. and B. Kaina, DNA damage-induced cell death: from specific DNA lesions to the DNA damage response and apoptosis. Cancer Lett, 2013. 332 (2): p. 237-48.

53. Rahmani Kukia, N., et al., Bio-Effects of TiO2 Nanoparticles on Human Colorectal Cancer and Umbilical Vein Endothelial Cell Lines. Asian Pacific journal of cancer prevention : APJCP, 2018. 19 (10): p. 2821-2829.

54. Silici, S., et al., The protective effect of royal jelly against cisplatin-induced renal oxidative stress in rats. World J Urol, 2011.29 (1): p. 127-32.

55. Ateyya, H., H. Yosef, and M.A. Nader, Ameliorative effect of trimetazidine on cisplatin-induced hepatotoxicity in rats. Can J Physiol Pharmacol, 2016. 94 (2): p. 225-230.

56. Eltahir, H.M. and M.H. Nazmy, Esomeprazole ameliorates CCl4 induced liver fibrosis in rats via modulating oxidative stress, inflammatory, fibrogenic and apoptotic markers. Biomed Pharmacother, 2018. 97: p. 1356-1365.

57. Safhi, M.M., Nephroprotective Effect of Zingerone against CCl4-Induced Renal Toxicity in Swiss Albino Mice: Molecular Mechanism. Oxidative Medicine and Cellular Longevity, 2018. 2018: p. 7.

58. Hong, S.H., et al., Anti-Proliferative and Pro-Apoptotic Effects of Licochalcone A through ROS-Mediated Cell Cycle Arrest and Apoptosis in Human Bladder Cancer Cells. International journal of molecular sciences, 2019.20 (15): p. 3820.

59. Chung, T.-W., et al., Sinularin induces DNA damage, G2/M phase arrest, and apoptosis in human hepatocellular carcinoma cells. BMC complementary and alternative medicine, 2017. 17 (1): p. 62-62.

60. Hadfield, J.A., et al., Tubulin and microtubules as targets for anticancer drugs. Prog Cell Cycle Res, 2003. 5: p. 309-25.

61. Weinstein, J.N., Drug discovery: Cell lines battle cancer. Nature, 2012. 483 (7391): p. 544-5.

62. Mirabelli, P., L. Coppola, and M. Salvatore, Cancer Cell Lines Are Useful Model Systems for Medical Research. Cancers, 2019.11 (8): p. 1098.

63. Kärber, G., Beitrag zur kollektiven Behandlung pharmakologischer Reihenversuche. Naunyn-Schmiedebergs Archiv für experimentelle pathologie und pharmakologie, 1931. $162(4)$ : p. 480-483.

64. Baravalia, Y., Y. Vaghasiya, and S. Chanda, Brine Shrimp Cytotoxicity, Anti-inflammatory and Analgesic Properties of Woodfordia fruticosa Kurz Flowers. Iran J Pharm Res, 2012. 11 (3): p. 851-61.

65. Galvao, J., et al., Unexpected low-dose toxicity of the universal solvent DMSO. Faseb j, 2014. 28(3): p. 1317-30.

66. Karaca, O., et al., Prevention of carbon tetrachloride-induced liver injury in rats by Omega-3 fatty acids. 2017. 33: p. 137-144.

67. Wang, Y., et al., The efficacy of combination therapy using adeno-associated virus-TRAIL targeting to telomerase activity and cisplatin in a mice model of hepatocellular carcinoma. Journal of Cancer Research and Clinical Oncology, 2010. 136 (12): p. 1827-1837.

Page $10 / 17$ 
68. Ohkawa, H., N. Ohishi, and K. Yagi, Assay for lipid peroxides in animal tissues by thiobarbituric acid reaction. Anal Biochem, 1979. 95 (2): p. $351-8$.

69. Ellman, G.L., Tissue sulfhydryl groups. Arch Biochem Biophys, 1959. 82 (1): p. 70-7.

70. Rotruck, J.T., et al., Selenium: biochemical role as a component of glutathione peroxidase. Science, 1973. 179 (4073): p. $588-590$.

71. Bergmeyer, H., J. Bergmeyer, and M. Grassl, Methods of enzymatic analysis vol. VI, 3rd edn. Verlag Chemie. 1983, Weinheim.

72. Habig, W.H., M.J. Pabst, and W.B. Jakoby, Glutathione S-transferases. The first enzymatic step in mercapturic acid formation. J Biol Chem, 1974. 249 (22): p. 7130-9.

73. Marklund, S. and G. Marklund, Involvement of the superoxide anion radical in the autoxidation of pyrogallol and a convenient assay for superoxide dismutase. Eur J Biochem, 1974. 47 (3): p. 469-74.

74. Shaban, N.Z., et al., Protective role of Punica granatum (pomegranate) peel and seed oil extracts on diethylnitrosamine and phenobarbital-induced hepatic injury in male rats. Food Chem, 2013. 141 (3): p. 1587-96.

75. SUZUKI, H. and K. SUZUKI, Rat hypoplastic kidney (hpk/hpk) induces renal anemia, hyperparathyroidism, and osteodystrophy at the end stage of renal failure. Journal of veterinary medical science, 1998. 60(10): p. 1051-1058.

76. Mosmann, T., Rapid colorimetric assay for cellular growth and survival: application to proliferation and cytotoxicity assays. J Immunol Methods, 1983.65 (1-2): p. 55-63.

77. Shanmugasundaram, T., et al., Biocompatible silver, gold and silver/gold alloy nanoparticles for enhanced cancer therapy: in vitro and in vivo perspectives. Nanoscale, 2017. 9 (43): p. 16773-16790.

\section{Tables}

Table 1. Primers used in the RT-PCR

\begin{tabular}{|lll|}
\hline Gene & $\begin{array}{l}\text { Forward primer } \\
(\mathbf{5}-\mathbf{3})\end{array}$ & $\begin{array}{l}\text { Reverse primer } \\
(\mathbf{5} \mathbf{5} \text { /3) }\end{array}$ \\
\hline Bcl-2 & ATCGCTCTGTGGATGACTGAGTAC & AGAGACAGCCAGGAGAAATCAAAC \\
\hline Bax & ACACCTGAGCTGACCTTG & AGCCCATGATGGTTCTGATC \\
Caspase- $\mathbf{8}$ & CTGGGAAGGATCGACGATTA & CATGTCCTGCATTTTGATGG \\
\hline -actin & AAGTCCCTCACCCTCCCAAAAG & AAGCAATGCTGTCACCTTCCC \\
\hline
\end{tabular}

Table 2: Karber's method for determination of LD50 of DBT and DBT-CSNPs on rats

\begin{tabular}{|c|c|c|c|c|c|c|c|c|c|}
\hline \multirow[t]{2}{*}{ Group } & \multirow{2}{*}{$\begin{array}{l}\text { Dose } \\
\text { (mg/kg) }\end{array}$} & \multirow{2}{*}{$\begin{array}{l}\text { Dose difference } \\
\text { (a) }\end{array}$} & \multirow{2}{*}{$\begin{array}{l}\text { No } \\
\text { of } \\
\text { rats }\end{array}$} & \multicolumn{3}{|c|}{ LD50 of DBT } & \multicolumn{3}{|c|}{ LD50 of DBT-CSNPs } \\
\hline & & & & $\begin{array}{l}\text { No of } \\
\text { dead }\end{array}$ & $\begin{array}{l}\text { Mean Mortality } \\
\text { (b) }\end{array}$ & $\begin{array}{l}\text { Product (a x } \\
\text { b) }\end{array}$ & $\begin{array}{l}\text { No of } \\
\text { dead }\end{array}$ & $\begin{array}{l}\text { Mean Mortality } \\
\text { (b) }\end{array}$ & $\begin{array}{l}\text { Product (a x } \\
\text { b) }\end{array}$ \\
\hline 1 & 200 & - & 4 & 0 & - & - & 0 & - & - \\
\hline 2 & 400 & 200 & 4 & 1 & 0.5 & 100 & 0 & - & - \\
\hline 3 & 800 & 400 & 4 & 1 & 1 & 400 & 1 & 0.5 & 200 \\
\hline 4 & 1200 & 400 & 4 & 2 & 1.5 & 600 & 1 & 1 & 400 \\
\hline 5 & 2000 & 800 & 4 & 3 & 2.5 & 2000 & 2 & 1.5 & 1200 \\
\hline 6 & 3000 & 1000 & 4 & 4 & 3.5 & 3500 & 4 & 3 & 3000 \\
\hline $\begin{array}{l}\text { Sum of } \\
\text { product }\end{array}$ & & & & & & 6600 & & & 4800 \\
\hline LD50 & & & & LD50 = & $0-(6600 / 4)=13$ & mg / kg & LD50 = & $0-(4800 / 4)=18$ & 0 mg /kg \\
\hline
\end{tabular}


Table 3. Effect of different compounds on liver and kidney functions and lipid profile

\begin{tabular}{|c|c|c|c|c|c|c|c|c|c|}
\hline Parameters & C & CSNPs & DBT & $\begin{array}{l}\text { DBT- } \\
\text { CSNPs }\end{array}$ & $\mathrm{CCl}_{4}$ & $\mathrm{CCl}_{4}$-CSNPs & $\mathrm{CCl}_{4}-\mathrm{DBT}$ & $\begin{array}{l}\mathrm{CCl}_{4} \text {-DBT- } \\
\text { CSNPs }\end{array}$ & $\mathrm{CCl}_{4}$-Cispla \\
\hline ALT (U/L) & $\begin{array}{l}117.72 \pm \\
2.54\end{array}$ & $119.32 \pm 2.56$ & $\begin{array}{l}131.58 \pm \\
3.74^{*}\end{array}$ & $\begin{array}{l}123.58 \pm \\
2.81^{*}\end{array}$ & $\begin{array}{l}265.52 \pm \\
4.33^{*}\end{array}$ & $258.31 \pm 3.89^{* a}$ & $188.33 \pm 2.74^{\star \# a}$ & $\begin{array}{l}157.92 \pm \\
6.09^{\star \#}\end{array}$ & $210.81 \pm 6.8$ \\
\hline AST (U/L) & $146.19 \pm 3.86$ & $148.3 \pm 3.69$ & $\begin{array}{l}155.78 \pm \\
5.4^{*}\end{array}$ & $151.7 \pm 4.7$ & $302.1 \pm 4.27^{\star}$ & $\begin{array}{l}293.61 \\
\pm 3.89^{\star} a\end{array}$ & $224.1 \pm 3.25^{\star \# a}$ & $\begin{array}{l}187.49 \pm \\
4.14^{\star \#}\end{array}$ & $\begin{array}{l}259.58 \pm \\
6.07^{\star \# a}\end{array}$ \\
\hline ALP (U/L) & & $256.25 \pm 2.09$ & & & & $446.49 \pm 5.41^{* a}$ & & & \\
\hline & $\begin{array}{l}252.85 \pm \\
2.08\end{array}$ & & $267.8 \pm 4.1^{*}$ & $\begin{array}{l}257.85 \pm \\
4.29\end{array}$ & $\begin{array}{l}456.31 \pm \\
5.58^{*}\end{array}$ & & $\begin{array}{l}352.16 \pm \\
4.05^{\star \# a}\end{array}$ & $\begin{array}{l}314.9 \pm \\
3.44^{* \#}\end{array}$ & $375.24 \pm 5.7$ \\
\hline $\mathrm{TP}(\mathrm{g} / \mathrm{dl})$ & & $5.81 \pm 0.037$ & & & & $5.06 \pm 0.039^{\star a}$ & & & \\
\hline & $5.89 \pm 0.042$ & & $\begin{array}{l}5.77 \pm \\
0.035\end{array}$ & $\begin{array}{l}5.86 \pm \\
0.037\end{array}$ & $\begin{array}{l}4.99 \pm \\
0.033^{*}\end{array}$ & & $5.57 \pm 0.045^{\star \#}$ & $\begin{array}{l}5.67 \pm \\
0.035^{\star \#}\end{array}$ & $5.08 \pm 0.09$ ! \\
\hline $\begin{array}{l}\text { Liver TP } \\
\text { (mg/ g } \\
\text { tissue) }\end{array}$ & $146.1 \pm 7.38$ & $142.6 \pm 3.92$ & $136.8 \pm 4.34$ & $141.2 \pm 3.77$ & $91.03 \pm 5.88^{*}$ & $87.21 \pm 5.22^{\star a}$ & $105.2 \pm 7.15^{\star \#}$ & $121.1 \pm 5.23^{\star \#}$ & $83.5 \pm 4.75^{*_{1}}$ \\
\hline Albumin & & $4.78 \pm 0.28$ & & & & $3.57 \pm 0.14^{\star a}$ & & & \\
\hline & $4.99 \pm 0.33$ & & $\begin{array}{l}4.29 \pm \\
0.063^{*}\end{array}$ & $\begin{array}{l}4.47 \pm \\
0.057^{\star}\end{array}$ & $3.48 \pm 0.15^{*}$ & & $3.91 \pm 0.025^{\star \#}$ & $\begin{array}{l}3.77 \pm \\
0.057^{\star \#}\end{array}$ & $3.35 \pm 0.05$ \\
\hline $\begin{array}{l}\text { Cholesterol } \\
(\mathrm{ma} / \mathrm{dl})\end{array}$ & & $90.3 \pm 2.31$ & & & & $160.7 \pm 4.21^{\star_{a}}$ & & & \\
\hline & $88.75 \pm 2.39$ & & $\begin{array}{l}98.17 \pm \\
3.98^{*}\end{array}$ & $\begin{array}{l}96.08 \pm \\
2.16^{*}\end{array}$ & $\begin{array}{l}165.44 \pm \\
2.32^{*}\end{array}$ & & $131.11 \pm 2.61^{\star \#}$ & $\begin{array}{l}128.94 \pm \\
2.57^{\star \#}\end{array}$ & $\begin{array}{l}153.78 \pm \\
2.39^{\star \# a}\end{array}$ \\
\hline TG (mg/dl) & $87.49 \pm 1.58$ & $89.2 \pm 1.62$ & $\begin{array}{l}96.08 \pm \\
2.16^{*}\end{array}$ & $\begin{array}{l}93.07 \pm \\
2.89^{*}\end{array}$ & $\begin{array}{l}148.03 \pm \\
2.27^{*}\end{array}$ & $145.9 \pm 3.26^{\star a}$ & $\begin{array}{l}128.75 \pm \\
1.67^{\star \# a}\end{array}$ & $\begin{array}{l}123.84 \pm \\
2.78^{\star \#}\end{array}$ & $133.3 \pm 1.9^{*}$ \\
\hline $\begin{array}{l}\text { LDL- } \\
\text { cholesterol } \\
\text { (mg/dl) }\end{array}$ & $55.61 \pm 1.5$ & $56.69 \pm 1.54$ & $64.19 \pm 3^{*}$ & $\begin{array}{l}58.69 \pm \\
1.54^{*}\end{array}$ & $93.1 \pm 1.87^{*}$ & $90.2 \pm 2.83^{* a}$ & $78.28 \pm 2.2^{\star \# a}$ & $\begin{array}{l}70.79 \pm \\
1.45^{\star \#}\end{array}$ & $86.59 \pm 2.0^{\circ}$ \\
\hline $\begin{array}{l}\text { HDL- } \\
\text { cholesterol } \\
\text { (mg/dl) }\end{array}$ & $47.61 \pm 1.45$ & $45.2 \pm 1.42$ & $\begin{array}{l}42.37 \pm \\
1.51^{*}\end{array}$ & $\begin{array}{l}43.88 \pm \\
1.86^{*}\end{array}$ & $\begin{array}{l}27.95 \pm \\
2.09^{*}\end{array}$ & $28.9 \pm 1.93^{* a}$ & $40.22 \pm 1.17^{\star \#}$ & $\begin{array}{l}41.42 \pm \\
0.87^{\star \#}\end{array}$ & $33.74 \pm 1.7$ \\
\hline $\begin{array}{l}\text { Urea } \\
(\mathrm{mg} / \mathrm{dl})\end{array}$ & $43.79 \pm 2.16$ & $45.2 \pm 2.19$ & $\begin{array}{l}48.74 \pm \\
2.35^{*}\end{array}$ & $\begin{array}{l}45.07 \pm \\
3.96\end{array}$ & $\begin{array}{l}73.21 \pm \\
2.98^{*}\end{array}$ & $71.6 \pm 1.09^{\star a}$ & $65.76 \pm 3.19^{\star \# a}$ & $\begin{array}{l}58.74 \pm \\
2.35^{\star \#}\end{array}$ & $69.74 \pm 2.21$ \\
\hline $\begin{array}{l}\text { Creatinine } \\
(\mathrm{mg} / \mathrm{dl})\end{array}$ & $0.95 \pm 0.02$ & 0.950 .13 & $\begin{array}{l}1.13 \pm \\
0.108^{*}\end{array}$ & $1.07 \pm 0.04^{*}$ & $1.5 \pm 0.068^{*}$ & $1.42 \pm 0.071^{* a}$ & $1.38 \pm 0.049^{\star \# a}$ & $\begin{array}{l}1.21 \pm \\
0.027^{\star}\end{array}$ & $1.44 \pm 0.04^{*}$ \\
\hline
\end{tabular}

Values represent the values mean \pm SD of 8 rats. One-way ANOVA followed with Tukey's test was used $\left(* P<0.05 v s\right.$. saline control group, \#P< 0.05 vs. CCl ${ }_{4}$ gr $\& a P<0.05$ vs. DBT-CSNPs treated group).

\section{Figures}




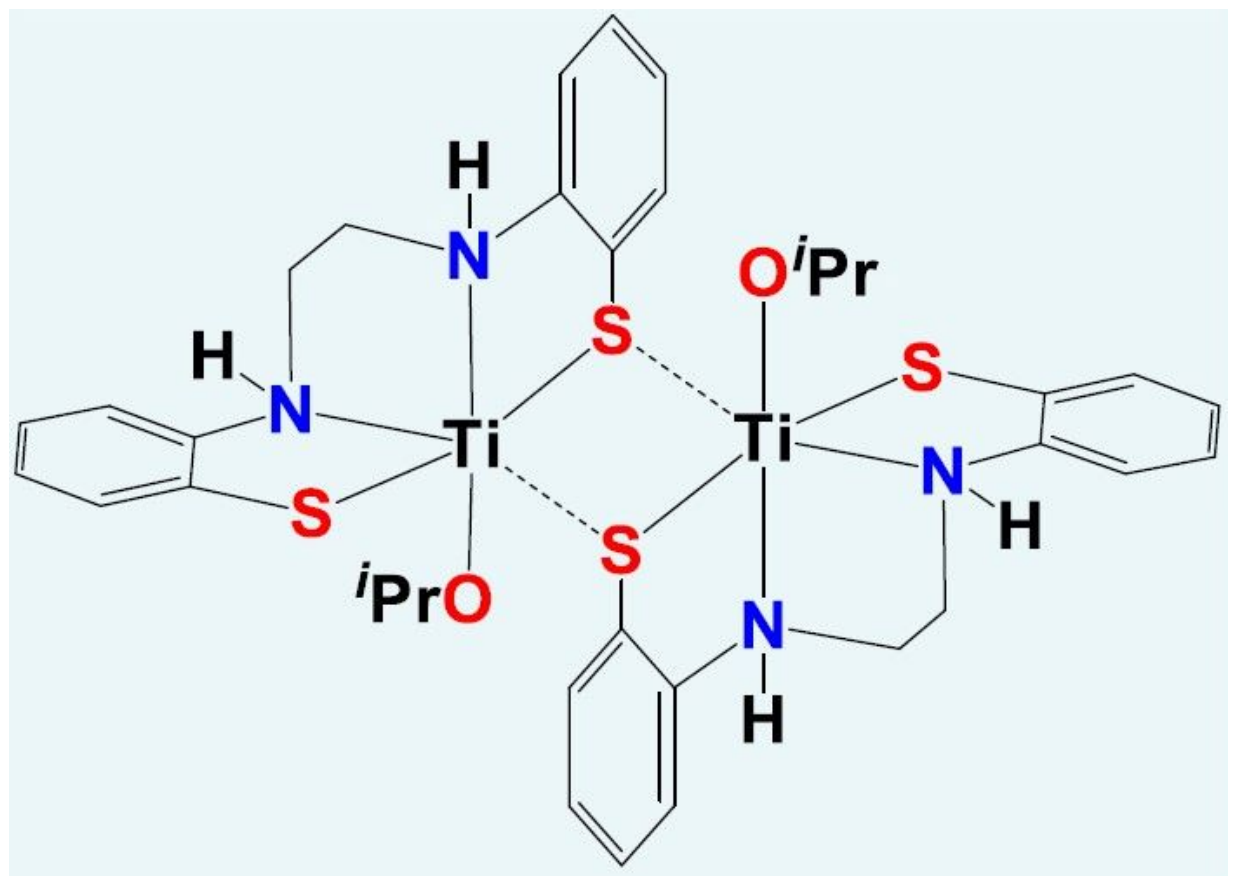

Figure 1

Dithiophenolato titanium (IV)-complex [\{Ti(N2H2S2) (OiPr) $\} \times 2]$ (DBT).

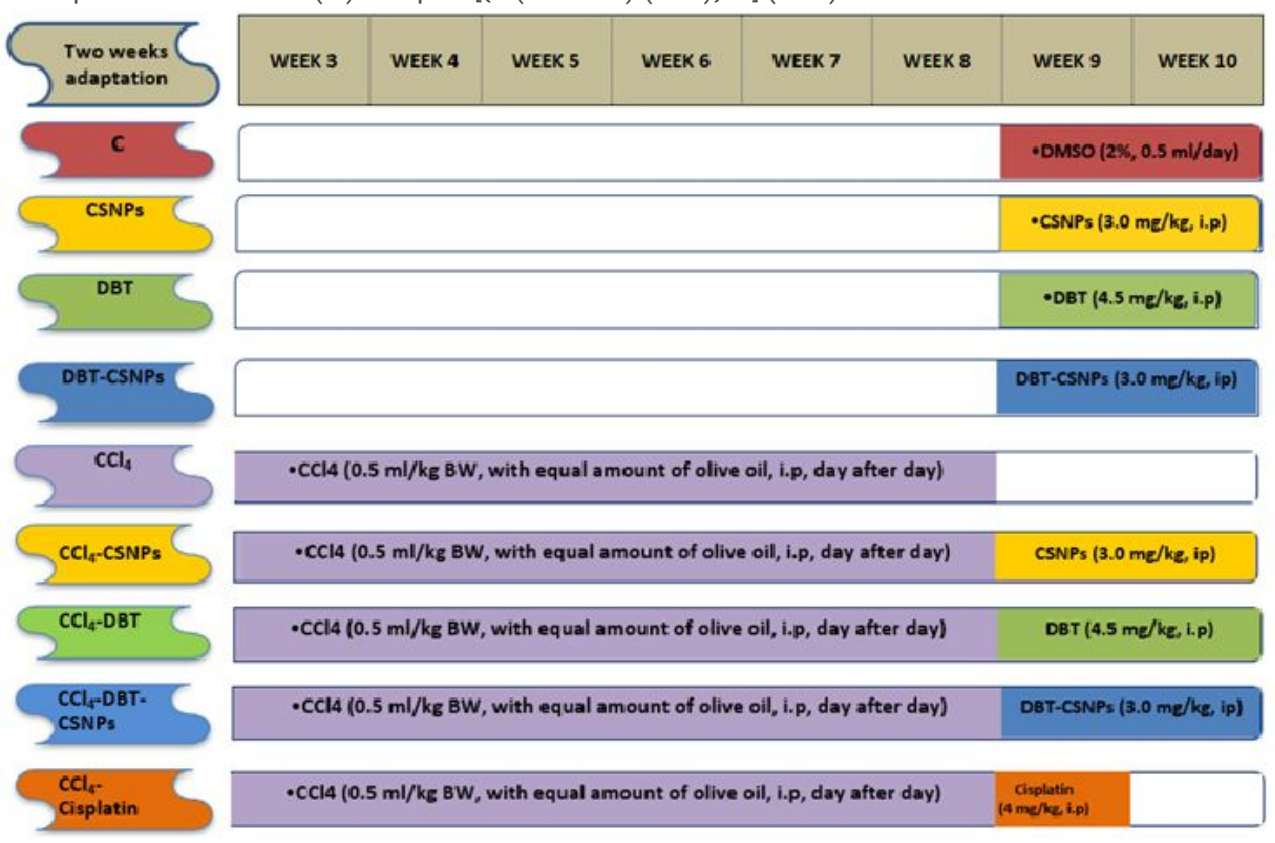

Figure 2

The experimental design 

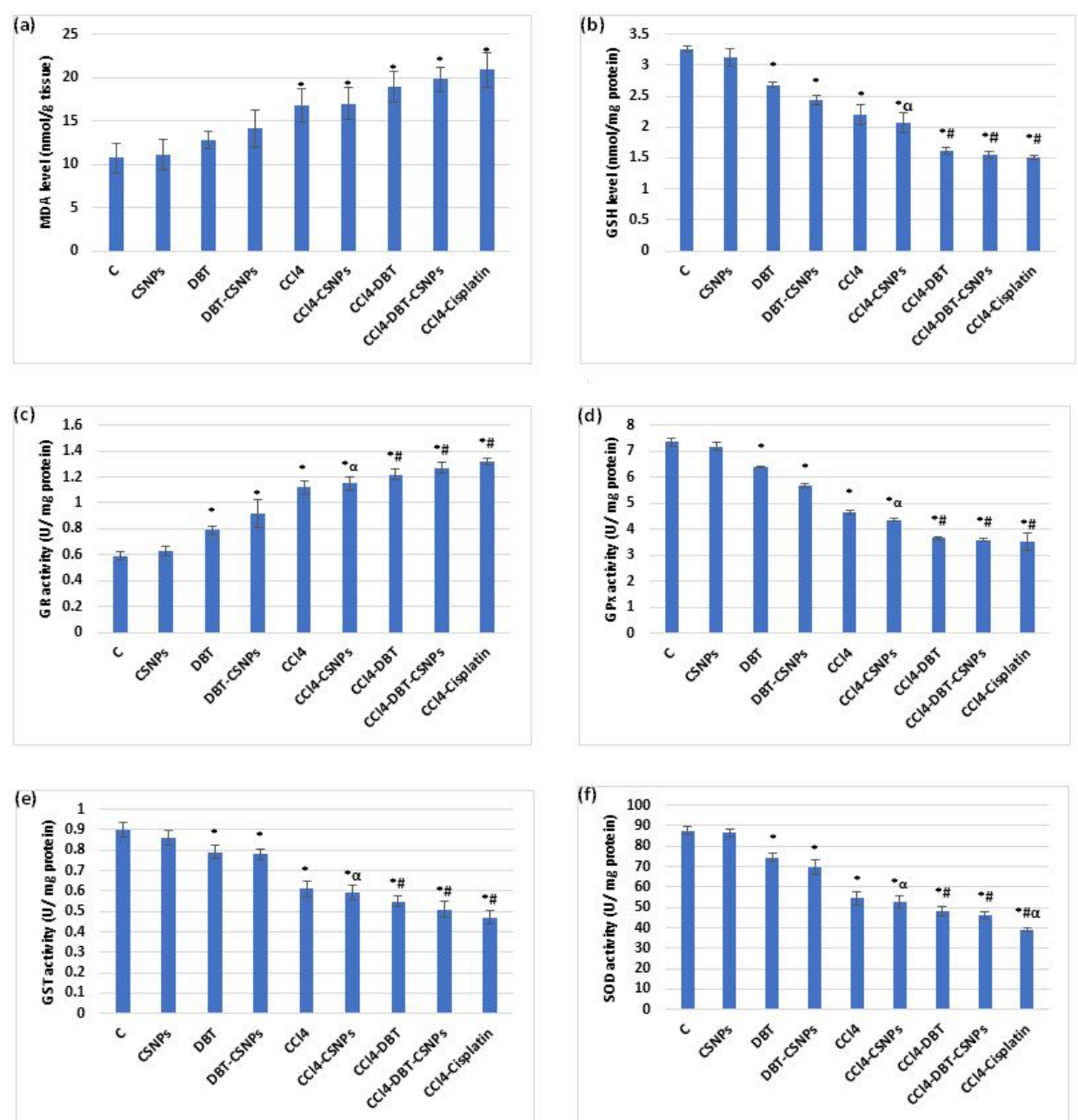

\section{Figure 3}

Effect of different compounds on oxidative stress parameters. (a) malondialdehyde (MDA), (b) glutathione (GSH), (c) glutathione reductase (GR), (d) glutathione peroxidase (GPx), (e) glutathione-S-transferase (GST), and (f) superoxide dismutase (SOD) activities. Values represent the values mean \pm SD of 8 rats. One-way ANOVA was used ( ${ }^{*} \mathrm{P}<0.05$ vs. saline control group, \# $\mathrm{P}<0.05$ vs. CCl4 group \& a $\mathrm{P}<0.05$ vs. DBT-CSNPs treated group). 
(a)

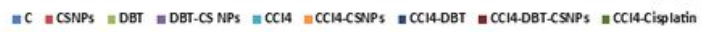

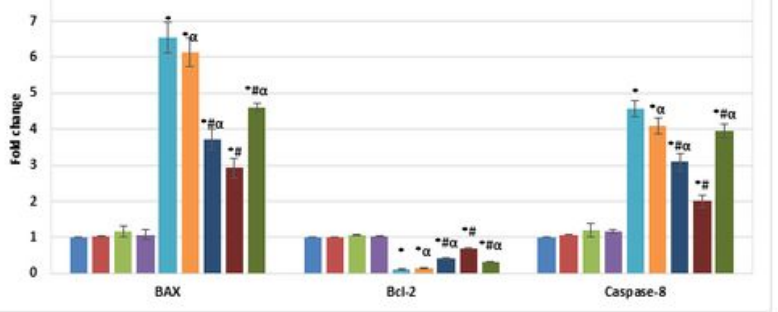

(b)

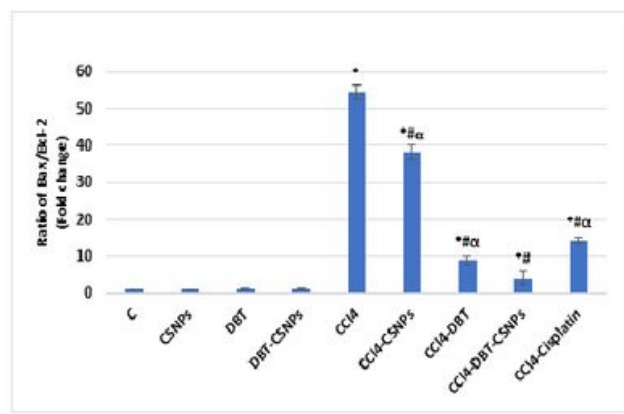

(c)

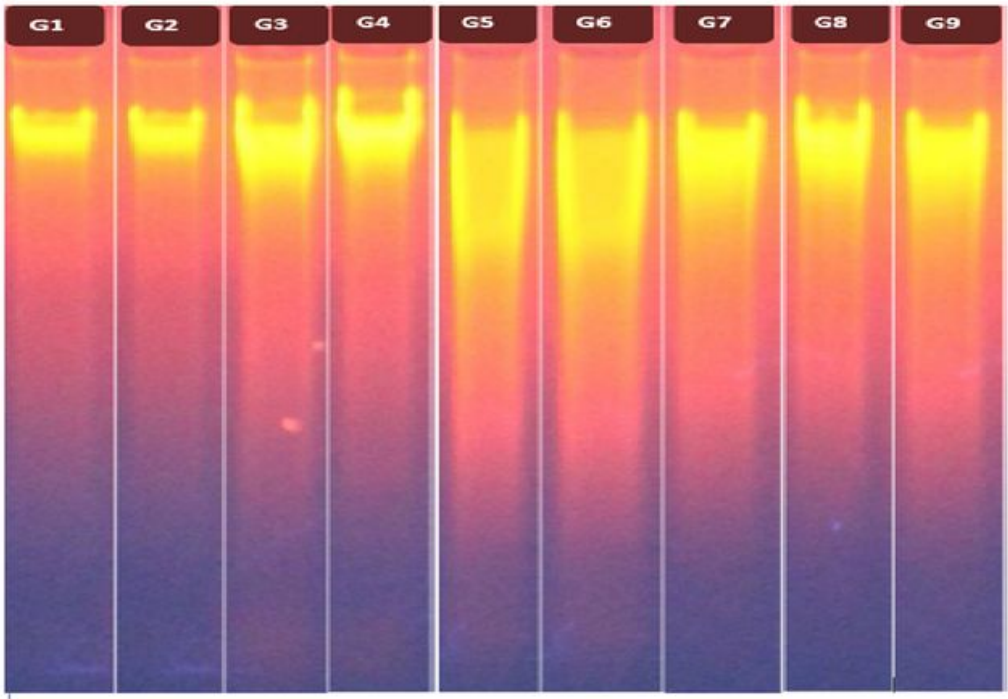

Figure 4

Effect of different compounds on apoptotic markers. (a) The mRNA levels of Bax, Bcl-2 and caspase-8. (b) Relative ratio of Bax/Bcl-2 mRNA. (c) DNAF. Gene expression was normalized to $\beta$-actin. Data are expressed as mean \pm SD of three rats. One-way analysis of variance (ANOVA) was used ( $* P<0.05$ vs. saline control group, $\# \mathrm{P}<0.05$ vs. CCl4 group \& a $\mathrm{P}<0.05$ vs. DBT-CSNPs treated group). In DNAF, ethidium bromide-stained agarose gel showing fragmentation patterns of the extracted DNA in the studied groups. G1: control, G2: DBT, G3: DBT-CSNPs, G4: CCl4, G5: CCl4-DBT, G6: CCI4-DBT-CSNPs and G7: CCl4-cisplatin. 

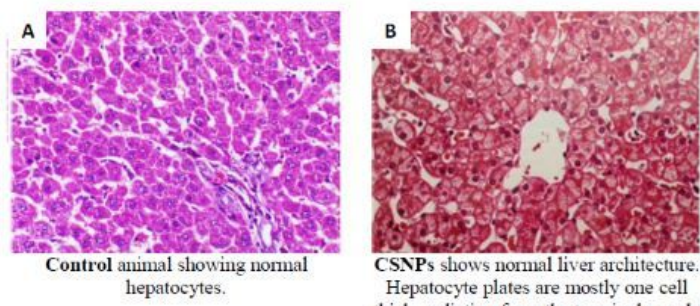

Hepatocyte plates are mostly one cell thick, radiating from the terminal venule
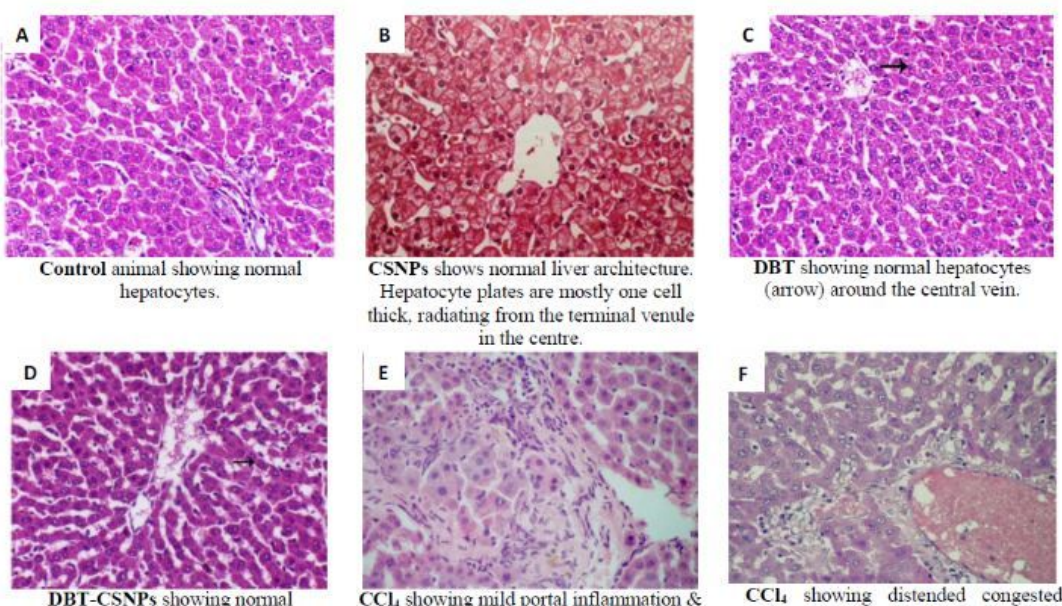

DBF-CSNPs

vein.

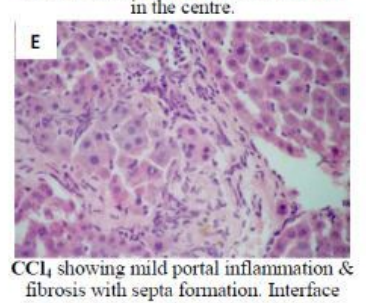

(arrow) around the central vein.

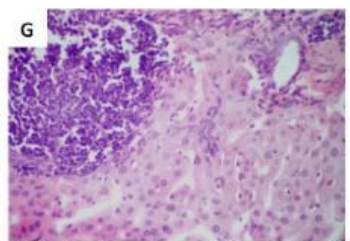

$\mathrm{CCl}_{4}$ showing a focus of lytic necrosis \& dispersed apoptotic bodies both intra extracellular in location

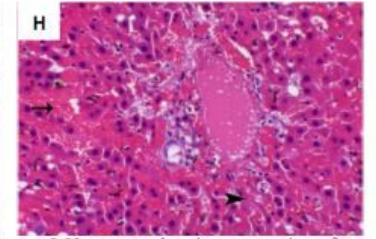

$\mathrm{CCl}_{4}$-CSNPs showing congestion of central vein and haemorrhage (arrow) and centrilobular hepatic necrosis

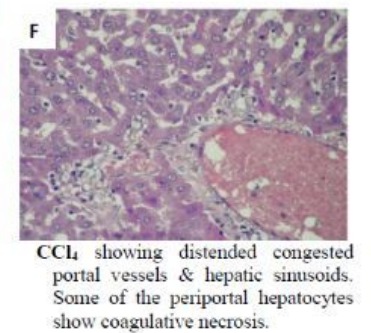
show coagulative necrosis.

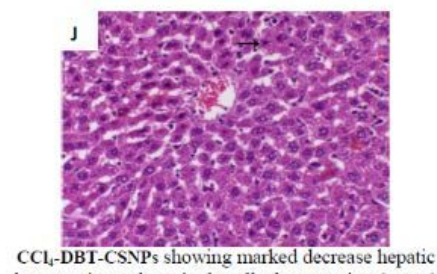

(arrowhead)

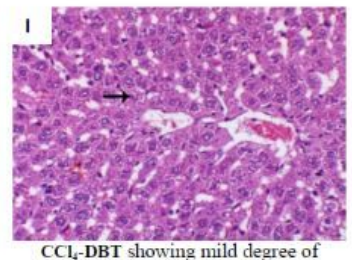

hepatic dowing mild degree of cell swelling (arrow).

degeneration unless single cells degeneration (arrow)

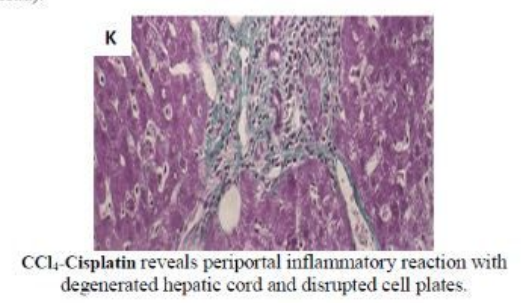

\section{Figure 5}

Effect of different compounds on the liver histopathology. H \& E stained sections of liver tissue from the different examined groups. A: control, B: DBT, C: DBTCSNPS, D-G: CCI4, H: CCI4-DBT, I: CCI4-DBT-CSNPs and J: CCl4-cisplatin (X200). Liver tissues of the control group showed normal lobular architecture, individual hepatocytes disclosed no pathology and the portal triad was unremarkable. Liver tissues of DBT and DBT-CSNPs groups exhibited normal hepatocytes around the central vein (Figure $5 \mathrm{~B}$ and C). Tissue sample of $\mathrm{CCl} 4$ intoxicated group indicated cellular infiltration, congestion of central vein, mild portal inflammation, hemorrhage as well as centrilobular hepatic necrosis and focus of lytic necrosis \& dispersed apoptotic bodies both intra \& extracellular in location (Figure $5 \mathrm{D}-\mathrm{G}$ ). The specimen of DBT treated rats confirmed a mild degree of hepatic degeneration represented by cell swelling (arrow), Figure $5 \mathrm{H}$. On the other hand, liver tissue of DBT-CSNPs treated rats revealed a marked decrease of hepatic degeneration unless single cells degeneration (arrow), Figure $5 \mathrm{I}$. Moreover, a periportal inflammatory reaction with degenerated hepatic cord and disrupts cell plates were observed in tissue of the cisplatin treated group, Figure $5 \mathrm{~J}$. These histopathological results revealed the hepatoprotective effects of DBT and DBT-CSNPs that confirm the biochemical analysis. 
(a)
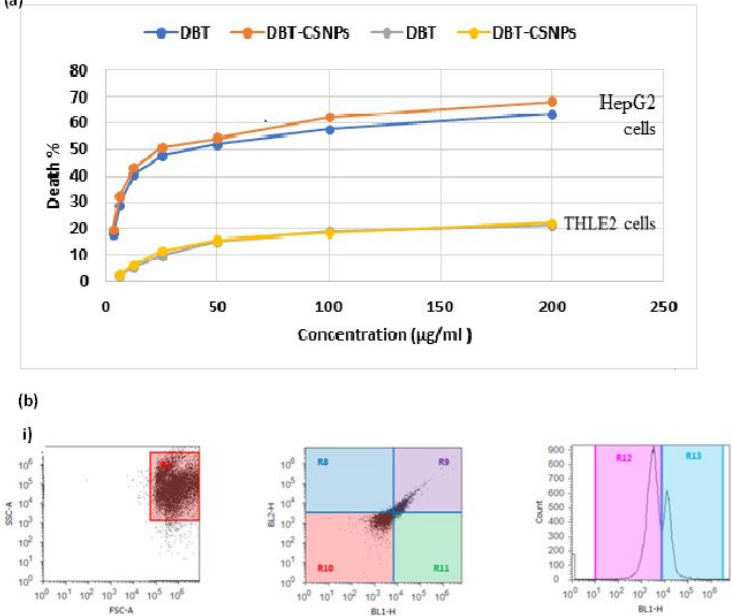

[G0/G1 $=60 \pm 2.83 \%, \mathbf{S}=16 \pm 1.04 \%, \mathbf{G} 2 / \mathrm{M}=24 \pm 1.23 \%]$
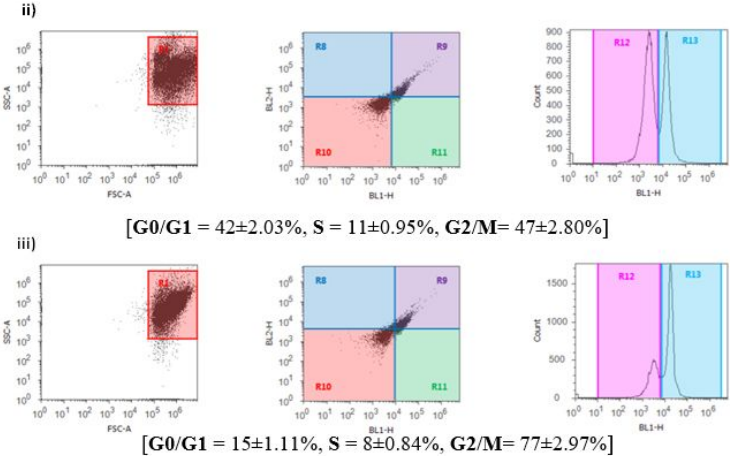

\section{Figure 6}

Flow cytometric analysis of control and treated HepG2 cells. (a) Control (b) DBT- treated HepG2 cells and (c) DBT-CSNPs- treated HepG2 cells. Values represent the values mean $\pm \operatorname{SD}(n=3)$.

\section{Supplementary Files}

This is a list of supplementary files associated with this preprint. Click to download.

- AbstractFigure.tif 